\title{
CONSERVATION STATUS OF TREE SPECIES IN HIMCHARI NATIONAL PARK OF COX'S BAZAR, BANGLADESH
}

\author{
Hossen, S. and M. K. Hossain \\ Institute of Forestry and Environmental Sciences, University of Chittagong, Chittagong-4331, \\ Bangladesh
}

\begin{abstract}
Himchari National Park (HNP) was declared as a Protected Area (PA) in 1980 under the section 23(II) of Bangladesh Wildlife Preservation Act 1974 of the Government of the People's Republic of Bangladesh. The total area of the HNP is about 1,729 ha (4,271.15 acres) under the jurisdiction of Cox's Bazar South Forest Division, Cox's Bazar district. Once the forest was very rich in flora and fauna, but many of the species have disappeared due to habitat destruction, over-exploitation, habitat fragmentation, fire hazard, encroachment, indiscriminate harvesting of tree species and Non-Timber Forest products. The study was conducted through extensive whole area survey and quadrat survey methods. A total of 117 tree species (having $\geq 5 \mathrm{~cm} \mathrm{dbh}$ ) belonging to 37 families was recorded from the HNP. Moraceae family possesses the highest species (14) followed by Mimosaceae (8), Euphorbiaceae (7), Myrtaceae (6) and 5 species each by Anacardiaceae, Caesalpiniaceae, Meliaceae and Verbenaceae. A total of 69 tree species (59\%) was found as Least Concern (LC) representing maximum tree species among all the categories. Vulnerable, Endangered, Near Threatened and Critically Endangered tree species were represented by 16 species (14\%), 4 species (3\%), 2 species (2\%) and 2 species $(2 \%)$, respectively. It is necessary to take effective measures for the protection, sustainable management, proper utilization and conservation of tree species in an aim to conserve the forest genetic resources of the Himchari natural forests.
\end{abstract}

Key words: National park, conservation, native tree species, forest genetic resources, threatened.

\section{INTRODUCTION}

Bangladesh vegetation is a part of the Indo-Myanmar region, which is one of the ten global hot spot areas for biodiversity (Mittermeier et al. 1998) and rich biological diversity due to its unique geophysical location (Hossain 2001, Barua et al. 2001, Chowdhury 2001, Nishat et al. 2002). The country has a rich biological heritage containing about 3,611 species of angiosperms (Khan et al. 2007), of which 2,260 species are reported from Chittagong region alone (Heinig 1925, Khan et al. 2007). The diversity of trees is fundamental to total tropical forest biodiversity, because tree provides resources and habitats for almost all other forest species (Huston 1994, Canon et al. 1998, Hall and Swaine 1976). The extent of biodiversity loss in Bangladesh is not exactly known due to very poor data base and often based on scarce information (Hossain et al. 2004). According to Rahman et al. (2000) and Hossain (2001) the depletion of native species is also accelerating at an alarming rate through rapid loss and degradation of forests in Bangladesh.

Biodiversity is surveyed for the conservation and management of natural habitat (Pielou 1995). Conserving biodiversity in an ecosystem is important since it is not always evident which species and what quantities of those species are necessary to maintain the ecosystem normal functioning (Burton $e t$ al. 1992). Information on the composition of a forest is essential for its wise management in terms of economic value and regeneration potential (Wyatt-Smith 1987), but very scanty information is available on the composition of this forest. Inventorying or assessment is essential for better understanding of the levels, distribution and dynamics of tree species of a particular forest. Presence of systematic records of the flora of a forest and its regeneration will help in formulating any plan to preserve its biodiversity. To achieve good conservation and management of our natural resources, we should have gone to know the status and structure of biological resources long before, especially of the tree species (Hossain et al. 2017). 
In Bangladesh, it is an urgent need to protect and manage the existing natural forests effectively for future generation (Hossain et al. 2017). Quantitative floristic inventories are fundamental to an understanding of the ecology of tropical forest and for developing national forest management strategies (Campbell et al. 1986, Reddy et al. 2011). The HNP, located in the southeastern region of Bangladesh comprising an area of 1,729 ha, was gazetted in 1980 and is very important due to its proximity to Cox's Bazar tourist city. Biodiversity assessment and evaluation is essential for taking effective conservation measures of this protected area immediately. Therefore, the study was envisaged to assess the diversity and conservation status of tree species in the Himchari National Park, Cox's Bazar district.

\section{MATERIAL AND METHODS}

Study area

The Himchari National Park is located $\left(21^{0} 35^{`}\right.$ to $21^{0} 44^{`} \mathrm{~N}$ and $91^{0} 98^{`}$ to $\left.92^{0} 05^{`} \mathrm{E}\right)$ on the outskirts of Cox's Bazar city extending from Lighthouse para on the north to Rejhukhal on the south with an expansion of around $17 \mathrm{~km}^{2}$. It consists of three unions, namely South Mithachari, Jhilongja and Khuniapalong union. In exercise of the power conferred by the section 23(II) of Bangladesh Wildlife Preservation Act 1974 the Government of the People's Republic of Bangladesh proclaimed the park measuring about 1729 ha $(4,271.15$ acres $)$ to be a National Park on $15^{\text {th }}$ February 1980. It was proclaimed as National Park under three forests block named Bhangamura Reserve Forest (872 ha), part of Chainda Reserve Forest (62 ha), and part of Jhilongja Protected Forest (795 ha). These three blocks at present cover four forest beats, namely Kolatoli, Chainda, Jhilongja and Link Road. The total landscape area of the Protected Forest (PF) is about 10,849 ha of which 1,729 ha core zone, 5,247 ha buffer zone and 3,873 ha private land. It is under the jurisdiction of Cox's Bazar South Forest Division within Cox's Bazar district (Fig. 1).

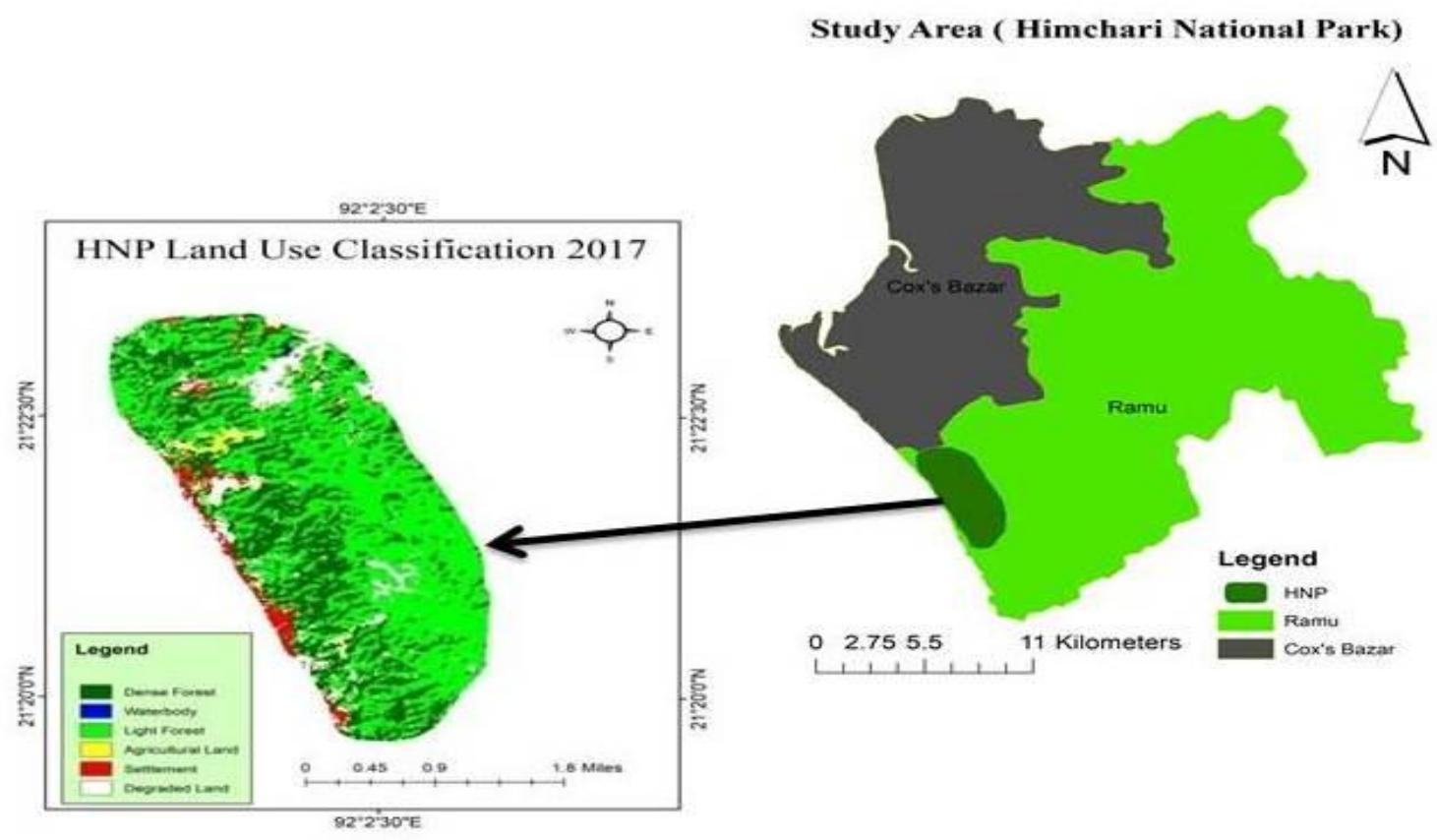

Fig.1. Map of Himchari National Park (Core and buffer Area)

\section{Reconnaissance survey}

The researchers visited the HNP to have an idea of tree species composition of the whole forest prior 
to selection of sampling procedure. A thorough field visit was conducted in the whole forest at the onset of the field work. A formal discussion was held with the concerned forest officials and some experienced forest villagers. A base map of the area was collected from the Forest Department. Detail information about the geography, land uses, plantations and present management systems were also collected from respective authority. Two transact walks (one from North to South and the other from East to West) across the forest were made with the help of the field assistants to familiarizing with the vegetation community, designing sampling design, planning accessibility and field works and to get an idea about the vegetation in the study area.

\section{Tree species status, composition, diversity and conservation status}

The study was conducted from January 2017 to May 2018. The composition and diversity of the tree species in the HNP were assessed through stratified random quadrat survey applied separately for tree species following Roy et al. (1993) and Rahman and Hossain (2002). The whole HNP was divided into four broad areas (blocks) considering beat area, namely Chainda, Jhilanga, Kalatali and Link Road. Total fifty one (51) plots in four experimental locations were taken by using simple random sampling. The number of quadrats was fixed considering the sample plot size $(20 \mathrm{~m} \mathrm{x} 20 \mathrm{~m})$ to have a sampling intensity of more than $0.231 \%$ for quantitative and qualitative measurement of the tree species throughout the sites. All trees having $\geq 5 \mathrm{~cm}$ dbh were identified, counted by individuals and measured in the quadrats.

\section{RESULTS AND DISCUSSION}

The conservation status of all the 117 tree species of the HNP was determined following the Encyclopedia of Flora and Fauna of Bangladesh (Ahmed et al. 2008). All the recorded trees were represented by 10 conservation categories, viz. Conservation Dependent (CD), Data Deficient (DD), Least Concern (LC), Not Evaluated (NE), Not Evaluated but seems to be rare (NE but seems rare), Near Threatened (NT), Vulnerable (VU), Lower Risk (LR), Endangered (EN) and Critically Endangered (CR). Out of a total of 117 species, 69 species (59\%) was found as Least Concern (LC) which represents maximum tree species among all the categories (Table 1). Whatsoever, Vulnerable, Endangered, Near Threatened and Critically Endangered tree species were represented by 16 species (14\%), 4 species (3\%), 2 species (2\%) and 2 species (2\%), respectively (Table 1 and Fig. 2).

Table 1. Tree species composition and conservation status of the Himchari National Park

\begin{tabular}{|c|c|c|c|c|}
\hline Family & $\begin{array}{c}\text { Species } \\
\text { No }\end{array}$ & Local Name & Scientific Name & $\begin{array}{c}\text { Conservation } \\
\text { Status } \\
\end{array}$ \\
\hline \multirow[t]{5}{*}{ Anacardiaceae } & 1 & Jialbhadi & Lannea coromandelica (Houtt.) Merr. & $\mathrm{LC}^{1}$ \\
\hline & 2 & Aam & Mangifera indica L. & $\mathrm{LC}^{1}$ \\
\hline & 3 & Uri Aam & Mangifera sylvatica Roxb. & $\mathrm{CR}^{2}$ \\
\hline & 4 & Civit & Swintonia floribunda Griff. & $\mathrm{VU}^{1}$ \\
\hline & 5 & Kaju Badam & Anacardium occidentale L. & $\mathrm{LC}^{1}$ \\
\hline \multirow[t]{2}{*}{ Annonaceae } & 6 & Debdaru & Polyalthia longifolia (Sonn.) & NE but seems rare ${ }^{1}$ \\
\hline & 7 & Ata & Annona reticulata $\mathrm{L}$. & $\mathrm{LC}^{1}$ \\
\hline \multirow[t]{2}{*}{ Apocynaceae } & 8 & Chatim & Alstonia scholaris (L.) & $\mathrm{LC}^{1}$ \\
\hline & 9 & Kuruch & $\begin{array}{l}\text { Holarrhena antidysenterica (L.) } \\
\text { Wall.ex Decne }\end{array}$ & $\mathrm{LC}^{1}$ \\
\hline \multirow[t]{4}{*}{ Arecaceae } & 10 & Tal & Borassus flabellifer L. & $\mathrm{LC}^{1}$ \\
\hline & 11 & Narikel & Cocos nucifera $\mathrm{L}$ & $\mathrm{LC}^{1}$ \\
\hline & 12 & Supari & Areca catechu L. & $\mathrm{LC}^{1}$ \\
\hline & 13 & Oil palm & Elaeis guineensis Jacq. & $\mathrm{NE}^{1}$ \\
\hline
\end{tabular}




\begin{tabular}{|c|c|c|c|c|}
\hline \multirow[t]{3}{*}{ Bignoniaceae } & 14 & Koida arsol & Stereospermum suaveolens (Roxb.) & $\mathrm{LR}^{1}$ \\
\hline & 15 & Dharmara & $\begin{array}{l}\text { Stereospermum colais (Buch.-Ham. ex } \\
\text { Dillw) }\end{array}$ & NE but seems rare \\
\hline & 16 & Bon Tula & Bombax insigne Wall. & NE but seems rare \\
\hline \multirow[t]{3}{*}{ Burseraceae } & 17 & Gutgotiya & $\begin{array}{l}\text { Protium serratum (Wall. ex. Colebr.) } \\
\text { Engl. }\end{array}$ & $\mathrm{VU}^{2}$ \\
\hline & 18 & Sil Bhadi & Garuga pinnata Roxb. & $\mathrm{LC}^{1}$ \\
\hline & 19 & Dhup & Canarium resiniferum Brace ex king & $\mathrm{CR}^{2}$ \\
\hline \multirow[t]{5}{*}{ Caesalpiniaceae } & 20 & Krishnachura & Delonix regia Rafin. & $\mathrm{LC}^{1}$ \\
\hline & 21 & Tentul & Tamarindus indica $\mathrm{L}$. & $\mathrm{LC}^{1}$ \\
\hline & 22 & Radhachura & Caesalpinia pulcherrima (L.) & $\mathrm{LC}^{\top}$ \\
\hline & 23 & Sonalu & Cassia fistula $\mathrm{L}$. & $\mathrm{LC}^{1}$ \\
\hline & 24 & Minjiri & Senna siamea (Lamk.) & $\mathrm{LC}^{1}$ \\
\hline Casuarinaceae & 25 & Jhau & Casuarina equisetifolia Forst. & $\mathrm{LC}^{1}$ \\
\hline \multirow[t]{3}{*}{ Clusiaceae } & 26 & Kao & Garcinia cowa Roxb. ex DC. & $\mathrm{VU}^{2}$ \\
\hline & 27 & Badujja gola & Garcinia lanceaefolia Roxb. & $\mathrm{NE}^{1}$ \\
\hline & 28 & Nagesswar & Mesua ferrea $\mathrm{L}$. & $\mathrm{LC}^{1}$ \\
\hline \multirow[t]{4}{*}{ Combretaceae } & 29 & Arjun & $\begin{array}{l}\text { Terminalia arjuna (Roxb. ex Dc.) } \\
\text { Wight \& Am. }\end{array}$ & $\mathrm{VU}^{\mathrm{I}}$ \\
\hline & 30 & Kath Badam & Terminalia catappa $\mathrm{L}$. & $\mathrm{LC}^{1}$ \\
\hline & 31 & Haritaki & Terminalia chebula Retz. & $\mathrm{VU}^{\mathrm{T}}$ \\
\hline & 32 & Bohera & Terminalia bellirica (Gaertin.) Roxb. & $\mathrm{LC}^{1}$ \\
\hline Dilleniaceae & 33 & Hargeza & Dillenia scabrella Roxb. ex Wall & $\mathrm{VU}^{2}$ \\
\hline \multirow[t]{4}{*}{ Dipterocarpaceae } & 34 & Telia Garjan & Dipterocarpus turbinatus Gaertin. & $\mathrm{LC}^{1}$ \\
\hline & 35 & Sal & Shorea robusta Roxb. ex Gaertin. f. & $\mathrm{LC}^{1}$ \\
\hline & 36 & Telsur & Hopea odorata Roxb. & $\mathrm{LC}^{1}$ \\
\hline & 37 & Boilam & Anisoptera scaphula (Roxb.)Pierre & $\mathrm{CD}^{1}$ \\
\hline Ebenaceae & 38 & Bongab & Diospyros montana Roxb. & $\mathrm{LC}^{1}$ \\
\hline \multirow[t]{2}{*}{ Elaeocarpaceae } & 39 & Jalpai & Elaeocarpus tectorius (Lour.)Poir & $\mathrm{EN}^{2}$ \\
\hline & 40 & Titpai & Elaeocarpus floribundus Blume & $\mathrm{EN}^{2}$ \\
\hline \multirow[t]{7}{*}{ Euphorbiaceae } & 41 & Amloki & Phyllanthus emblica L. & $\mathrm{LC}^{1}$ \\
\hline & 42 & Bura & $\begin{array}{l}\text { Macaranga denticulata (B1.) Muell.- } \\
\text { Arg. }\end{array}$ & $\mathrm{LC}^{1}$ \\
\hline & 43 & Moricha & Suregada multiflora (A. Juss.) Bail. & $\mathrm{NE}^{\mathrm{T}}$ \\
\hline & 44 & Castoma & Aporosa wallichii Hook.f. & $\mathrm{NE}^{\mathrm{T}}$ \\
\hline & 45 & Sindur & $\begin{array}{l}\text { Mallotus philippensis (Lamk.). Muell.- } \\
\text { Arg. }\end{array}$ & $\mathrm{CD}^{1}$ \\
\hline & 46 & Nunia Bura & Macaranga indica Wight & $\mathrm{VU}^{\mathrm{I}}$ \\
\hline & 47 & Chitki & Phyllanthus reticulatus Poir. & $\mathrm{LC}^{1}$ \\
\hline \multirow[t]{3}{*}{ Fabaceae } & 48 & Palash & Butea monosperma (Lamk.) Taub. & $\mathrm{LC}^{\top}$ \\
\hline & 49 & Mandar & Erythrina variegata $\mathrm{L}$. & $\mathrm{LC}^{1}$ \\
\hline & 50 & Sisso & Dalbergia sissoo Roxb. & $\mathrm{LC}^{1}$ \\
\hline \multirow[t]{3}{*}{ Fagaceae } & 51 & Kali Batna & $\begin{array}{l}\text { Lithocarpus elegans var.elegans } \\
\text { (Blume) Hatus.ex Soepad }\end{array}$ & $\mathrm{EN}^{2}$ \\
\hline & 52 & Dholi Batna & Lithocarpus acuminata (Roxb.)Rehder & $\mathrm{EN}^{1}$ \\
\hline & 53 & Batna & $\begin{array}{l}\text { Lithocarpus polystachya (Wall. ex } \\
\text { A.DC.) Rehder }\end{array}$ & $\mathrm{NT}^{1}$ \\
\hline Juglandaceae & 54 & $\begin{array}{c}\text { Jhumka } \\
\text { Bhadi }\end{array}$ & $\begin{array}{l}\text { Engelhardtia spicata Leschen ex } \\
\text { Blume }\end{array}$ & $\mathrm{VU}^{2}$ \\
\hline \multirow[t]{3}{*}{ Lauraceae } & 55 & Menda & Litsea glutinosa (Lour.) C.B. Robinson & $\mathrm{LC}^{1}$ \\
\hline & 56 & Manda & Litsea monopetala (Roxb.) Pers. & $\mathrm{NE}^{\mathrm{I}}$ \\
\hline & 57 & Modanmosta & Actinodaphne angustifolia Nees & $\mathrm{NE}^{1}$ \\
\hline
\end{tabular}




\begin{tabular}{|c|c|c|c|c|}
\hline & 58 & Tez-Bohu & Cinnamoтит iners Reinw. Ex Blume & $\mathrm{VU}^{2}$ \\
\hline Lythraceae & 59 & Jarul & Lagerstroemia speciosa (L.) Pers. & $\mathrm{LC}^{1}$ \\
\hline Magnoliaceae & 60 & Champa & Michelia champaca $\mathrm{L}$. & $\mathrm{VU}^{2}$ \\
\hline \multirow[t]{5}{*}{ Meliaceae } & 61 & Chickrassi & Chukrasia tabularis A. Juss. & $\mathrm{VU}^{2}$ \\
\hline & 62 & Mahagoni & Swietenia mahagoni Jacq. & $\mathrm{LC}^{1}$ \\
\hline & 63 & Neem & Azadirachta indica A. Juss & $\mathrm{LC}^{1}$ \\
\hline & 64 & Toon & Toona ciliata Roem. & $\mathrm{CD}^{1}$ \\
\hline & 65 & Pitraj, Royna & Aphanamixis polystachya (Wall.) Parker. & $\mathrm{VU}^{2}$ \\
\hline \multirow[t]{8}{*}{ Mimosaceae } & 66 & Sada Koroi & Albizia procera (Roxb.) Benth. & $\mathrm{LC}^{\mathrm{T}}$ \\
\hline & 67 & Akashmoni & $\begin{array}{l}\text { Acacia auriculiformis A. Cunn. ex } \\
\text { Benth. \& Hook. }\end{array}$ & $\mathrm{LC}^{1}$ \\
\hline & 68 & Mangium & Acacia mangium Willd. & $\mathrm{LC}^{\mathrm{T}}$ \\
\hline & 69 & Kala Koroi & Albizia lebbeck (L.) Benth. \& Hook. & $\mathrm{LC}^{1}$ \\
\hline & 70 & Raintree & Samanea saman (Jacq.) Merr. & $\mathrm{LC}^{1}$ \\
\hline & 71 & Loha Kath & Xylia xylocarpa Roxb. Taub. & $\mathrm{LC}^{\top}$ \\
\hline & 72 & Ipil Ipil & $\begin{array}{l}\text { Leucaena leucocephala (Lamk.) de } \\
\text { Wit }\end{array}$ & $\mathrm{LC}^{1}$ \\
\hline & 73 & Chakua Koroi & Albizia chinensis (Osb.) Merr. & $\mathrm{LC}^{1}$ \\
\hline \multirow[t]{14}{*}{ Moraceae } & 74 & Dumur & Ficus hispida L.f. & $\mathrm{LC}^{1}$ \\
\hline & 75 & Boro Dumur & Ficus lanceolata Buch.-Ham. ex Roxb. & $\mathrm{VU}^{\mathrm{T}}$ \\
\hline & 76 & Kanthal & Artocarpus heterophyllus Lamk. & $\mathrm{LC}^{1}$ \\
\hline & 77 & Lal Dumur & Ficus auriculata Lour. & $\mathrm{LC}^{1}$ \\
\hline & 78 & Bot & Ficus benghalensis L. & $\mathrm{LC}^{\mathrm{I}}$ \\
\hline & 79 & Chapalish & Artocarpus chama Buch.-Ham. & NE but seems rare ${ }^{1}$ \\
\hline & 80 & Jigbot & Ficus lamponga Miq. & $\mathrm{LC}^{1}$ \\
\hline & 81 & Borta & Artocarpus lacucha Buch.-Ham & $\mathrm{LC}^{1}$ \\
\hline & 82 & Jogya Dumur & Ficus racemosa $\mathrm{L}$. & $\mathrm{LC}^{\mathrm{T}}$ \\
\hline & 83 & Jiribot & Ficus benjamina $\mathrm{L}$. & $\mathrm{LC}^{1}$ \\
\hline & 84 & Puti Bot & Ficus microcarpa L.f. & NE but seems rare ${ }^{1}$ \\
\hline & 85 & Asswat & Ficus religiosa $\mathrm{L}$. & $\mathrm{LC}^{\mathrm{I}}$ \\
\hline & 86 & Dol Dumur & Ficus conglobate King & $\mathrm{NE}^{\mathrm{T}}$ \\
\hline & 87 & Churkigola & Ficus semicordata Buch.-Ham. ex Smith & $\mathrm{NE}^{\mathrm{I}}$ \\
\hline Myrsinceae & 88 & Maesa & Maesa indica (Roxb.) A. DC. & $\mathrm{CD}^{1}$ \\
\hline \multirow[t]{6}{*}{ Myrtaceae } & 89 & Peyara & Psidium guajava $\mathrm{L}$. & $\mathrm{LC}^{1}$ \\
\hline & 90 & Puti Jam & Syzygium fruticosum DC. & $\mathrm{DD}^{1}$ \\
\hline & 91 & Dhaki Jam & Syzygium firmum Thw. & $\mathrm{LC}^{\mathrm{T}}$ \\
\hline & 92 & Kalo Jam & Syzygium cumini (L.) Skeels & $\mathrm{LC}^{\mathrm{I}}$ \\
\hline & 93 & Eucalyptus & Eucalyptus camaldulensis Dehnhardt. & $\mathrm{NE}^{\mathrm{T}}$ \\
\hline & 94 & Noli Jam & $\begin{array}{l}\text { Syzygium claviflorum (Roxb.) A.M. } \\
\text { Cowan \& J.M. Cowan }\end{array}$ & $\mathrm{LC}^{1}$ \\
\hline \multirow[t]{2}{*}{ Oxalidaceae } & 95 & Kamranga & Averrhoa carambola $\mathrm{L}$. & $\mathrm{LC}^{\top}$ \\
\hline & 96 & Belumbo & Averrhoa bilimbi $\mathrm{L}$. & $\mathrm{LC}^{\top}$ \\
\hline Rhamnaceae & 97 & Boroi & Ziziphus mauritiana Lamk. & $\mathrm{LC}^{1}$ \\
\hline \multirow[t]{3}{*}{ Rubiaceae } & 98 & Kadam & Neolamarckia cadamba (Roxb.) Bosser & $\mathrm{LC}^{1}$ \\
\hline & 99 & Dakuram & Mitragyna parvifolia (Roxb.) Korth & $\mathrm{CD}^{1}$ \\
\hline & 100 & Kom & Neonauclea sessilifolia (Roxb.) Merr. & $\mathrm{CD}^{1}$ \\
\hline \multirow[t]{3}{*}{ Rutaceae } & 101 & Jambura & Citrus maxima (Burm.) Merr. & $\mathrm{LC}^{1}$ \\
\hline & 102 & Bonjamir & Acronychia pedunculata (L.) Miq. & $\mathrm{NE}^{\mathrm{T}}$ \\
\hline & 103 & Kamini & Murraya paniculata (L.) Jack & $\mathrm{LC}^{1}$ \\
\hline Sabiaceae & 104 & Utailla & Meliosma simplicifolia (Roxb.) Walp. & $\mathrm{NT}^{\mathrm{T}}$ \\
\hline Sapindaceae & 105 & Harina & Lepisanthes rubiginosa (Roxb.) Leenh & $\mathrm{LC}^{1}$ \\
\hline Sapotaceae & 106 & Bokul & Mimusops elengi $\mathrm{L}$. & $\mathrm{LC}^{1}$ \\
\hline Sterculiaceae & 107 & Mostali & Sterculia guttata Roxb. & $\mathrm{LC}^{1}$ \\
\hline
\end{tabular}




\begin{tabular}{|c|c|c|c|c|}
\hline & 108 & Udal & Sterculia villosa Roxb. ex Smith & $\mathrm{LC}^{1}$ \\
\hline Thymeliaceae & 109 & Agar & Aquilaria agallocha Roxb. & $\mathrm{LC}^{1}$ \\
\hline \multirow[t]{3}{*}{ Tiliaceae } & 110 & Moos & Brownlowia elata Roxb. & $\mathrm{VU}^{1}$ \\
\hline & 111 & Assargola & Grewia nervosa (Lour.) Panigrahi & $\mathrm{LC}^{1}$ \\
\hline & 112 & Naricha & Grweia serrulata DC. & $\mathrm{LC}^{1}$ \\
\hline \multirow[t]{5}{*}{ Verbenaceae } & 113 & Gamar & Gmelina arborea Roxb. & $\mathrm{LC}^{1}$ \\
\hline & 114 & Segun & Tectona grandis L.f. & $\mathrm{LC}^{1}$ \\
\hline & 115 & Bormala & Callicarpa arborea Roxb. & NE but seems rare ${ }^{1}$ \\
\hline & 116 & Goda & $\begin{array}{l}\text { Vitex peduncularis Wall. ex Schauer in } \\
\text { A.DC. }\end{array}$ & $\mathrm{VU}^{2}$ \\
\hline & 117 & Horina arsol & Vitex pinnata $\mathrm{L}$. & $\mathrm{VU}^{2}$ \\
\hline
\end{tabular}

(Sources: 1- Ahmed et al. (2008); 2- Field Observation/Experience)

The tree species recorded were represented in different conservation categories, viz. Conservation Dependent (CD), Data Deficient (DD), Least Concern (LC), Not Evaluated (NE), Lower Risk (LR), Not Evaluated but seems to be rare (NE but seems rare), Near Threatened (NT), Vulnerable (VU), Endangered (EN) and Critically Endangered (CR) (Fig. 2).

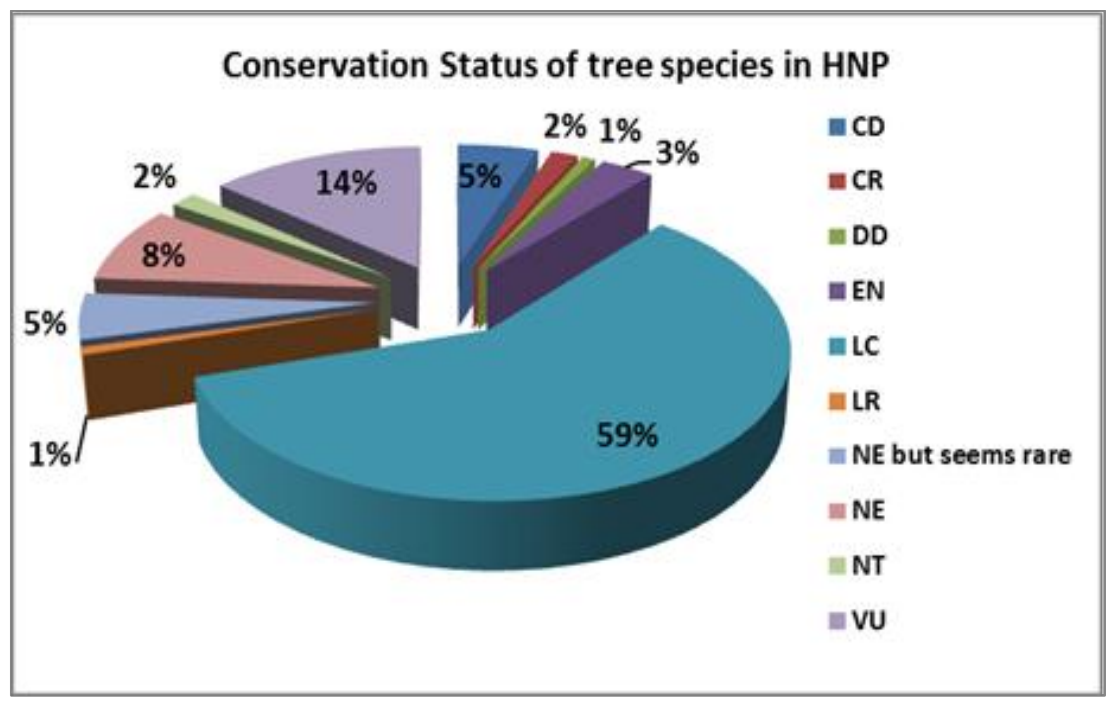

Fig. 2. Percentage of the recorded tree species under different conservation categories.

$[C D=$ Conservation Dependent, $D D=$ Data Deficient, $L C=$ Least Concern, $N E=$ Not Evaluated, $N E$ but seems rare $=$ Not Evaluated but seems to be rare, $N T=$ Near Threatened, $V U=$ Vulnerable, $L R=$ Lower Risk, EN =Endangered and $C R=$ Critically Endangered. $]$

A total of 88 tree species belonging to 64 genera and 37 families was recorded from the quadrats. On the other hand, 117 tree species belonging to 87 genera and 37 families recorded from both the quadrat and transacts study (Table1). Moraceae family possesses the highest species (14) followed by Mimosaceae (8), Euphorbiaceae (7), Myrtaceae (6), and having five species each by Anacardiaceae, Caesalpiniaceae, Meliaceae and Verbenaceae (Fig. 3).

The present study revealed the Himchari National Park as a diverse natural forest being represented by 117 tree species. The tree composition of the HNP (117 tree species under 87 genera and 37 families) is quite greater than 85 tree species reported from the Bamu reserve forest of Cox's Bazar (Hossain et al. 2004); 92 tree species from the Chunati Wildlife Sanctuary (Rahman and Hossain 2002); 102 tree species from the Boroitoli forest (Rahman et al. 2004); 62 tree species from the Tankawati Natural forest (Motaleb and Hossain 2011); 77 tree species from the Dudhpukuria Natural forest (Hossain et al. 
2012). But, it is quite lower in comparison to the 153-tree species reported from the tropical forests of Eastern Ghats, India (Reddy et al. 2011); 162 tree species from the primary forests of Garo Hills, India (Kumar et al. 2006).

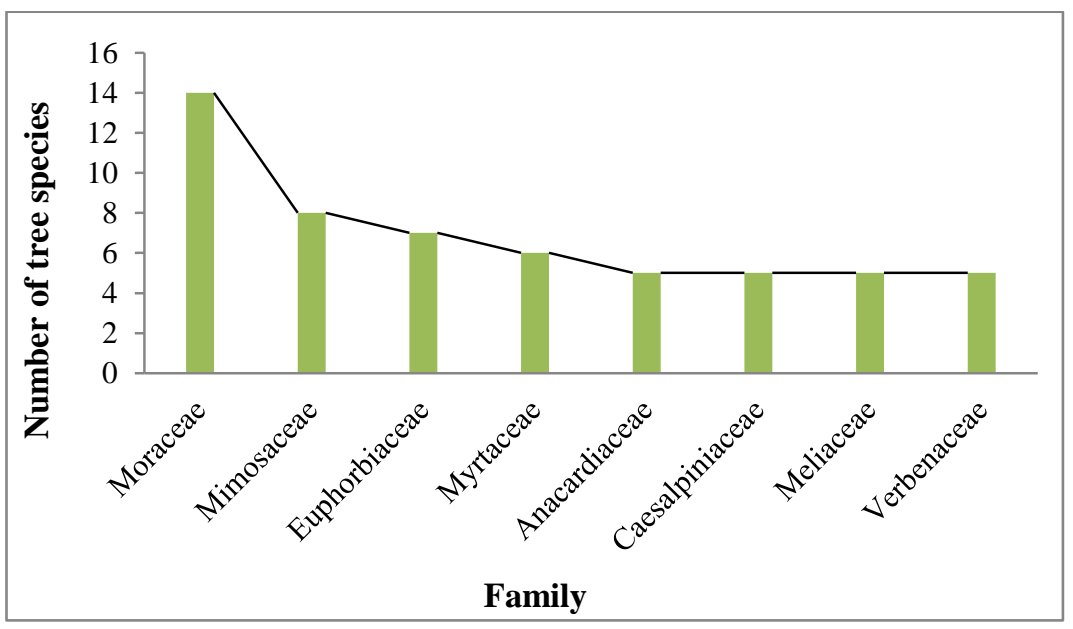

Fig. 3. Top eight families at the Himchari National Park with maximum tree species.

The extraction of all kinds of forest products and trespassing, that disturbs the natural habitat, are prohibited in the HNP. Community Forest Workers (CFW) are also helping the Forest Department (FD) personnel in patrolling forest resources from all illegal activities and extraction. As a result, the surrounding people who are generally used to cut and collect timber, fuel wood, bamboos, fence posts, agricultural implements and house posts from the forests are not allowed to do the same by their own community. However, the existing threats in conserving biodiversity of the HNP are also immense.

The main issues in the loss of tree diversity in the HNP are degradation of habitat, e.g. change in land use, conversion of forest lands to agricultural lands, haphazard introduction and priority of alien invasive species, expansion of road networks and other anthropogenic activities that have damage most of the forest resources of the HNP. Over exploitation of resources, e.g. collection of resources, fire hazard, illicit felling, encroachment, indiscriminate harvesting of tree species and Non-Timber Forest products exerts a significant negative impact on the biodiversity of the HNP. The process of conserving tree species can be divided into three phases: i) identification-determining which species are in danger of extinction, ii) protection-determining and implementing the short term measures necessary to halt species from extinction, iii) recovery-determining and implementing the long-term measures necessary to rebuild the population of the species to the point at which it is no longer in danger of extinction.

Although some natural regeneration was coming up, the cutting of seedlings and saplings particularly by fuel wood collectors and betel leaf cultivators impose threats on new recruitments. Many local people living in and around the national park area are dependent on the forests for their livelihood and daily necessary goods. Conflicts regarding land need to be resolved to protect trees and natural regeneration. At the same time periodic monitoring is needed to identify what changes are taking place on the composition, structure and diversity of tree species. Finally, it can be noted that the condition of the forest is poor, but still there is some hope as shown by the rich regeneration and potential of rehabilitation in the remnant natural forest. If it is possible to protect the National Park in the current state with effective measures of diverting the forest dependent people towards non forest related livelihood alternatives or reducing dependency on the forest, there is a greater possibility of this forest to develop into a better quality forest ecosystem with native tree species. 


\section{ACKNOWLEDGEMENTS}

The authors are thankful to the Institute of Forestry and Environmental Sciences, Chittagong University (IFESCU), Bangladesh Forest Research Institute (BFRI), Cox's Bazar South Forest Division and local people of HNP for their cordial collaboration and cooperation.

\section{REFERENCES}

Ahmed, Z. U., Z. N. T. Begum, M. A. Hassan, M. Khondker, S. M. H. Kabir, M. Ahmad, A. T. A. Ahmed, A. K. A. Rahman and E. U. Haque (eds.). 2008. Encyclopedia of Flora and Fauna of Bangladesh. Vol. 5-12. Asiatic Society of Bangladesh, Dhaka.

Barua, S. P., M. M. H. Khan and A. H. M. A. Reza. 2001. The Status of Alien Invasive Species in Bangladesh and their Impact on the Ecosystems. In: P. Balakrishna (ed.). Alien Invasive Species Report of workshop on Alien Invasive Species. IUCN Regional Biodiversity Programme of Asia. Colombo, Sri Lanka., pp. 1-7.

Burton, P. J., A. C. Balisky, L. P. Coward, S. G. Cumming and D. D. Kneeshaw. 1992. The value of managing for biodiversity. Forest Chronicles. 6: 225-237.

Campbell, D. G., D. C. Daly, G. T. Prance and U. N. Maciel. 1986. Quantitative Ecological Inventory of Terra Firm and Varzea Tropical Forest on the United Nations. Regional Office for Asia and the Pacific, Bangkok. 88 pp.

Canon, C. H., D. R. Peart and M. Leighton. 1998.Tree species diversity in commercially logged bornean rain forest. Science. 28: 1366-1368.

Chowdhury, Q. I. 2001. Bangladesh: State of Bio-diversity. Forum of Environmental Journalists of Bangladesh (FEJB). Shegun Bagicha, Dhaka, Bangladesh., pp. 9-15.

Hall, J. B. and M. D. Swaine. 1976. Classification and ecology of closed-canopy forest in Ghana. J. Ecol. 64: 913-951.

Heinig, R.L. 1925. List of Plants of Chittagong Hill Tracts. The Bengal Government Branch Press, Darjeeling., pp. 1-84.

Hossain, M. D., M. A. Hossain and M. K. Hossain. 2012. Composition and diversity of tree species in Dud Pukuria Natural Forests of Chittagong (South) Forest Division, Bangladesh. Bangladesh J. Forest Sci. 32: 10-19.

Hossain, M. K. 2001. Overview of the forest biodiversity in Bangladesh. Assessment, conservation and sustainable use of forest biodiversity (CBD Technical Series no. 3). Montreal, SCBD, Canada. Secretariat of the Convention on Biological Diversity., pp. 33-35.

Hossain, M. K., M. L. Rahman, A. T. M. R. Hoque and M. K. Alam. 2004.Comparative regeneration status in a natural forest and enrichment plantations of Chittagong (South) Forest Division, Bangladesh. J. Forestry Res. 15(4): 255-260.

Hossain, M. K., M. S. Alam and M. A. Hossain. 2017. Conservation of Threatened Tree Species in Chittagong University Campus. Arannayk Foundation. Dhaka, Bangladesh. 183 pp.

Huston, M.A. 1994. Biol.Diversity. The Co-existence of Species on Changing landscape. Cambridge University Press, Cambridge, UK. 681 pp.

Khan, M. A. S. A., M. B. Uddin, M. S. Uddin, M. S. H. Chowdhury and S. A. Mukul. 2007. Distribution and Status of Forests in the Tropic: Bangladesh Perspective. Proc. Pakistan Acad. Sci. 44: 145-153.

Kumar, A., B. G. Marcot and A. Saxena. 2006. Tree species diversity and distribution patterns in tropical forests of Garo Hills, India. Current Sci. 91: 1370-1381.

Mittermeier, R. A., N. Myers, J. B. Thomsen, G. A. Defonseca and S. Olivieri. 1998. Biodiversity hotspots and major tropical wilderness areas: approaches to setting conservation priorities. Conserv. Biol. 12: 516-520. 
Motaleb, M.A. and M.K. Hossain. 2011. Assessment of tree species diversity of Tankawati natural forests, Chittagong (South) Forest Division. Bangladesh. Eco-Friendly Agricultural J. 4: 542-545.

Nishat, A., S. M. I. Huq, S. P. Barua, A. H. M. A. Reza and A. S. M. Khan. 2002. Bioecological Zones of Bangladesh. Dhaka. The World Conservation Union (IUCN) country office, Dhaka, Bangladesh., pp. 33-101.

Pielou, E. C. 1995. Species diversity and pattern diversity in the study of ecological succession. $J$. Theoretical Biol. 10: 370-383.

Rahman, M. A., M. H. Rashid and C. C. Wilcock. 2000. Diversity, Ecology, Distribution and Ethnobotany of the Apocynaceae of Bangladesh. Bangladesh J. Plant Taxon. 7(2): 57-76.

Rahman, M. L. and M. K. Hossain. 2002. Distribution pattern of medicinal tree species in Chunati wildlife sanctuary of Chittagong. J. Tropic. Medicinal Plants. 3(1): 65-72.

Rahman, M. L., M. K. Hossain, A. T. M. R. Hoque and M. K. Alam. 2004. Habit form distribution of plant species in Boroitoli forest- a tropical rain forest of Chittagong (south) forest division. Bangladesh J. Forest Environ. 2: 55-66.

Reddy, C. S., S. M. Barbar, G. Amarnath and C. Pattanaik. 2011. Structure and floristic composition of tree stand in tropical forest in the Eastern Ghats of Northern Andrhra Pradesh, India. J. Forestry Res. 22(4): 491-500.

Roy, P. S., S. Singh and M. C. Porwal. 1993. Characterization of ecological parameters in tropical community: A remote sensing approach. J. Indian Soc. Remote Sensing. 21: 127-149.

Wyatt-Smith, J. 1987. Problems and prospects for natural management of tropical moist forests. In: F. Mergen and J. R. Vincent (eds.). Natural Management of Tropical Moist Forests. Silvicultural and Management Prospects of Sustained Utilization. New Haven. Connecticut, Yale University, USA., pp. 9-22. 
